\title{
Radical Scavenging and Antibacterial Activity of Phenolic Compounds from Anacardium occidentale L. Stem Barks from South East Sulawesi-Indonesia
}

\author{
WAHYUNI, M. H. MALAKA, N. A. YANTI' ${ }^{1}$ R. HARTATI ${ }^{2}$, SUKRASNO² AND I. SAHIDIN*
}

Faculty of Pharmacy, ${ }^{1}$ Laboratory of Microbiology, Faculty of Mathematics and Natural Sciences, Universitas Halu Oleo, Kendari 93232, ${ }^{2}$ School of Pharmacy, Institut Teknologi Bandung, 40132, Indonesia

Wahyuni, et al.: Radical Scavenging and Antibacterial Potencies of Anacardium occidentale Stem Barks

\begin{abstract}
Three phenolic compounds, pinostrobin, pinocembrin and 4-hydroxybenzaldehide have been isolated and identified for the first time from methanol extract of Anacardium occidentale $\mathrm{L}$. stem bark. The isolation was carried out using various techniques of chromatography such as thin layer chromatography, vacuum liquid chromatography and radial chromatography. Silica gel as adsorbent and a mixture of solvents as eluent were used during the separation process. Structures of the isolated compounds were determined by Fourier transforms infrared, mass and nuclear magnetic resonance (1- and 2-Dimensi) spectroscopies. Biological properties of the isolated compounds were evaluated against four strains of bacteria (Shigella dysenteriae ATCC 13313, Salmonella typhi YCTC, methicillin-resistant Staphylococcus aureus ATCC33591, and Escherichia coli ATCC 35219), as well as the radical scavenging potential in DPPH assay. Results indicated that pinocembrin was the most active isolated compound towards $S$. dysenteriae, $S$. typhi, methicillin-resistant $S$. aureus and $E$. coli, however in comparison to the $\mathrm{MIC}_{50}$ value of the standard, pinocembrin possessed low antibacterial activity. Meanwhile, 4-hydroxybenzaldehide showed the highest radical scavenger activity with $\mathrm{IC}_{50}$ value of $134.93 \pm 0.13 \mu \mathrm{M}$, but much lower compared to vitamin $\mathrm{C}$ with $\mathrm{IC}_{50}$ value of $63.32 \pm 0.22 \mu \mathrm{M}$.
\end{abstract}

Key words: Anacardium occidentale, pinocembrin, pinostrobin, 4-hydroxybenzaldehide, antibacterial, radical scavenging activity

South East Sulawesi province (Indonesia) is located at Wallacea line, so this area has big biodiversity of both plants and animals. Our laboratory was involved in evaluating chemical and pharmacological aspects of traditional medicinal plants and in that process we previously reported our studies on plants of Dipterocarpaceae family ${ }^{[1-3]}$, Jatroph $^{[4-6]}$, Annonaceae family $^{[7]}$, Pongamia ${ }^{[8]}$, Imperata ${ }^{[9]}$, Polygonum ${ }^{[10,11]}$ and Dillenia ${ }^{[12]}$. The present investigation dealt with phytochemical and pharmacological evaluation of Anacardium plants available in the South East Sulawesi Province.

Anacardium occidentale L. (cashew) growths widely in this province. This plant is an important plantation crop in contributing to the national economy ${ }^{[13]}$. It produces various secondary metabolites, which have interesting biological activities. In Indonesia, the plant is used as a purgative (roots), for aphtha (stems and barks), dermatitis and combustion (leaves), as a food and for dermatitis (fruits) and seeds for food ${ }^{[14]}$. Moreover, an infusion of the barks and leaves is used to relieve a toothache and sore gums, while the young leaves are used for the treatment of dysentery, diarrhoea and piles ${ }^{[15,16]}$. In West Africa and South America, people used the leaves infusion in the treatment of gastrointestinal disorders, mouth ulcers and throat problems ${ }^{[17]}$. In addition, the cashew stem barks are utilized by Portuguese as an alternative antidiabetic medicine $^{[18]}$.

Previous pharmacological studies indicated that $A$. occidentale has various activities such as antiinflammatory, immunomodulatory,

This is an open access article distributed under the terms of the Creative Commons Attribution-NonCommercial-ShareAlike 3.0 License, which allows others to remix, tweak, and build upon the work non-commercially, as long as the author is credited and the new creations are licensed under the identical terms

Accepted 07 December 2017

Revised 22 April 2017

Received 05 November 2016

Indian J Pharm Sci 2018;80(1):143-149 
hypocholesterolemic, antioxidant, and antimicrobials ${ }^{[19]}$. The plant from Brazil has potency as an antiulcer and inhibits the activity of several enzymes like lipooxygenase and cyclooxygenase ${ }^{[20]}$. In addition, extracts of the leaves and barks of $A$. occidentale from Benin is active against Escherichia coli, Staphylococcus aureus, S. epidermidis, Pseudomonas aeruginosa, Proteus mirabilis, Micrococcus luteus, $P$. vulgaris, Streptococcus oralis, Enterococcus faecalis and Candida albicans ${ }^{[21]}$. The stem barks from Portugal and Nigeria, also has good potential as antioxidants ${ }^{[22,23]}$ and antiinflammatory ${ }^{[24]}$. Furthermore, leaves and nuts extract of this plant from India showed cytotoxicity against several tumor cell lines and also provided an analgesic effect ${ }^{[25,26]}$.

Phytochemical studies reported that A. occidentale produced both phenolic and non-phenolic compounds ${ }^{[24]}$. Cardol, cardanol and anacardic acid are isolated from nut-shells ${ }^{[27,28]}$. Catechin, epicatechin, carotene, lutein and tocopherol are extracted from kernels of cashew nuts ${ }^{[29]}$. The leaves produce agathistflavone and mixture of quercetine-3O-rutinoside and quercetine-3-O-rhamnoside ${ }^{[17]}$, and carotenoids are got from cashew apples ${ }^{[30]}$. Stem barks and artificial fruits also contain phenolic compounds, flavonoids, tannins, and alkaloids ${ }^{[25]}$. The flavonoids were agathisflavone ${ }^{[31]}$, mirisetin, miristrin, rhamnetin, quercetin, and kaempferol ${ }^{[32]}$.

To further explore the stem barks of $A$. occidentale, a study on the secondary metabolites and biological properties of the isolated compounds against some strains of bacteria and 2,2-diphenyl-1-picrylhydrazyl (DPPH) assay would be still very interesting. In this paper, we have reported the isolation and structure determinations of phenolic compounds from stem barks of A. occidentale and their potential as antibacterial and radical scavenging agents. Selected bacteria used were Shigella dysenteriae ATCC 13313, Salmonella typhi YCTC, methicillin-resistant Staphylococcus aureus (MRSA) ATCC 33591, and Escherichia coli ATCC 35219.

\section{MATERIALS AND METHODS}

Isolation of secondary metabolites was carried out at Laboratory of Pharmacy Universitas Halu Oleo by using thin layer chromatography (TLC), vacuum liquids chromatography (VLC) and radial chromatography (RC). VLC and RC were performed by employing silica gel $60 \mathrm{GF}$ as an adsorbent and a mixture of solvents as eluent. Melting points were determined on a Buchi MP-1665 melting point apparatus and uncorrected. Proton $\left({ }^{1} \mathrm{H}\right)$ and carbon-13 nuclear magnetic resonance $\left({ }^{13} \mathrm{C}\right.$ NMR) spectra were recorded with a JEOL ECP 500 spectrometer, operating at 500 $\mathrm{MHz}\left({ }^{1} \mathrm{H}\right)$ and $125 \mathrm{MHz}\left({ }^{13} \mathrm{C}\right)$, worked at LIPI Serpong, Indonesia. Molecular mass was analysed by MS Waters LCT Premier XE, Detector TOF, solvent: acetone+ $0.1 \%$ formic acid in acetonitrile:water (1:1) in Institute Teknologi Bandung, Indonesia. Chloramphenicol and vitamin $\mathrm{C}$ are positive control for antibacterial and radical scavenger activities, respectively.

\section{Collection of plant material and isolation of secondary metabolites:}

Samples of the stem barks of $A$. occidentale were collected from Kendari, South East Sulawesi. The plant was identified in School of Life Science, Institut Teknologi Bandung, Indonesia. The stem bark powder of $A$. occidentale $(1 \mathrm{~kg}$ ) was macerated with methanol for $3 \times 24 \mathrm{~h}$. The methanol extract was concentrated by vacuum rotary evaporator at low/reduced pressure, giving a brown gummy solid (50 g). The extract was fractioned twice using VLC (25 g; column diameter, $\Phi: 10 \mathrm{~cm}$, silica gel: $150 \mathrm{~g}$ ) by increasing polarity (n-hexane, n-hexane-ethyl acetate, ethyl acetate, methanol) to give 18 fractions, which were grouped into 4 major fractions by combining fractions with similar TLC profiles, F1 (6.1 g), F2 (13.0 g), F3 $(12.1 \mathrm{~g})$, and F4 (10.2 g). F1 fractioned by VLC using a column $\Phi 5 \mathrm{~cm}$, adsorbent: silica gel $(80 \mathrm{~g})$ and mixture of ethylacetate: $n$-hexane $(10: 100 \%$, methanol $100 \%)$ as eluent to get 5 fractions i.e F11 $(0.3 \mathrm{~g})$, F12 (0.2 g), F13 (1.1 g), F14 (0.8 g) and F15 (1.4 g). Purification of F14 using RC, adsorbent: silica gel and eluent n-hexane-ethylacetate $(30: 70 \%)$, to give compound 1 (25 mg), a yellow amorphous powder. F2 refraction by conducting VLC with a column $\Phi 5 \mathrm{~cm}$, adsorbent:silica gel $(80 \mathrm{~g})$ and mixture of ethylacetate:n-hexane (20:100\%, methanol $100 \%)$ as eluent, to give 4 fractions, i.e., F21 (1.1 g), F22 (1.9 g), F23 (3.2 g), and F24 (4.2 g). Purification of F21 gave compound 2, a yellow amorphous powder (18 mg). F22 was purified by RC, adsorbent: silica gel and the eluent mixture of ethylacetate:n-hexane $(30: 100 \%$, the methanol $100 \%$ ), to give compound $3(22 \mathrm{mg})$, a pale yellow crystalline.

\section{Antibacterial activity:}

The antimicrobial activity of the isolated compounds from $A$. occidentale stem barks was carried out by employing the disc diffusion method outlined by 
CLSI Guidelines, 2007. A $20 \mathrm{mg} / \mathrm{ml}$ stock solution of each compound was prepared by using dimethyl sulfoxide (DMSO). Blank discs were impregnated with $20 \mathrm{ml}$ of each compound $(400 \mathrm{mg} / \mathrm{ml})$ and allowed to dry. The bacterial isolates, grown overnight on brain heart infusion or tryptone soya agar plates, were suspended in sterile distilled water and the turbidity of cell suspensions adjusted equivalent to that of a $0.5 \mathrm{McF}$ arland standard. These were used to inoculate Mueller-Hilton agar plates by spreading swabs over the entire agar surface followed by the application of the respective compounds. Then, plates were incubated for $24 \mathrm{~h}$ at $37^{\circ}$. Testing was worked in duplicate and chloramphenicol (Sigma) was used as standard antimicrobial agent controls, while DMSOimpregnated discs were used as negative controls. Zone diameters were determined and averaged. Minimum inhibitory concentration (MIC) of isolated compounds were determined by microdilution methods ${ }^{[33]}$. The concentration of which there was no visually detectable bacterial growth was taken as the $\mathrm{MIC}^{[34]}$. The MIC is the lowest concentration of the compound at which the microorganism tested does not demonstrate visible growth (turbidity).

\section{Radical scavenger activity:}

The radical scavenging activity of the isolated compounds was adapted from Sahidin et al. ${ }^{[11]}$ and Ching et al. ${ }^{[35]}$ with slight modification. The reduction of DPPH radical was analysed by using both qualitative and quantitative methods. One millilitre of $500 \mu \mathrm{M}$ $(0.2 \mathrm{mg} / \mathrm{ml}) \mathrm{DPPH}$ in methanol was mixed with the same volumes as of the tested compounds at various concentrations. They were mixed well and kept in the dark for $30 \mathrm{~min}$. The absorbance at $\lambda 517 \mathrm{~nm}$ was monitored in the presence of different concentrations of the samples. The blank experiment, i.e. with only solvent and DPPH ( $2 \mathrm{ml}$ of $500 \mu \mathrm{M}$ in methanol), was also carried out to determine the absorbance of DPPH before interacting with the compounds. The amount of sample, compounds and standard (vitamin C) in $\mathrm{mg} / \mathrm{ml}$ at which the absorbance at $517 \mathrm{~nm}$ decreased to half of its initial value was used as the $\mathrm{IC}_{50}$ of compounds. The analysis was done in triplicate for the standard and compounds.

\section{Statistical analysis:}

Data were expressed as mean \pm standard deviation (SD) for three parallel measurements using IBM SPSS Statistics 19 for Windows ${ }^{\circledR}$, IBM, USA. Statistical analysis was done by post hoc test and $\mathrm{p}<0.05$ considered as significant.

\section{RESULTS AND DISCUSSION}

Pinostrobin (1), a yellow amorphous powder, melting point (MP): $102-103^{\circ}$. Spectrum of UV/Vis $(\mathrm{MeOH})$ $\lambda_{\max }(\mathrm{nm}): 212$ and 288. Fourier transform infrared (FTIR) spectrum (KBr), $v_{\max }\left(\mathrm{cm}^{-1}\right): 3430(-\mathrm{OH}), 2905$ $\left(\mathrm{Csp}^{3}-\mathrm{H}\right), 1649(\mathrm{C}=\mathrm{O}), 1510,1445,1401$ (aromatic), 1302, 1158 (C-O ether). Spectrum of ${ }^{1} \mathrm{H}-\mathrm{NMR}$ (500 $\left.\mathrm{MHz}, \mathrm{CDCl}_{3}\right) \delta_{\mathrm{H}}(\mathrm{ppm}): 2.68(1 \mathrm{H}, d d, J=14.5,3.0 \mathrm{~Hz})$, $2.95(1 \mathrm{H}, d d, J=16.5,2.4 \mathrm{~Hz}) ; 3.68(3 \mathrm{H}, s) ; 5.26(1 \mathrm{H}, d$, $J=3.0) ; 5.97(1 \mathrm{H}, d, J=4.0) ; 6.02(1 \mathrm{H}, d, J=4.0) ; 7.33$ $(2 \mathrm{H}, m), 7.36(1 \mathrm{H}, m), 7.39(2 \mathrm{H}, m), 12.04\left(1 \mathrm{H}_{\text {chelated }}\right.$ ? s). Spectrum of ${ }^{13} \mathrm{C}-\mathrm{NMR}\left(125 \mathrm{MHz}, \mathrm{CDCl}_{3}\right) \delta_{\mathrm{C}}(\mathrm{ppm})$ : 42.8; 55.2; 78.7; 93.9; 94.7; 102.7; 125.8 (2C); 128.4; 128.5 (2C); 138.1; 162.4; 163.7; 167.5; and 195.4. HRMS-ESI-TOF: $\mathrm{m} / \mathrm{z}[\mathrm{M}+\mathrm{H}]^{+}$calcd. for $\mathrm{C}_{16} \mathrm{H}_{14} \mathrm{O}_{4}$ 271,0970, found 271,0973.

Pinocembrin (2), a yellow amorphous powder, MP: $188-190^{\circ}$. UV/Vis spectrum $(\mathrm{MeOH}) \lambda_{\max }(\mathrm{nm}): 210$, 289. Spectrum of FTIR $(\mathrm{KBr}), v_{\max }\left(\mathrm{cm}^{-1}\right): 3512(\mathrm{OH})$, $2910\left(\mathrm{C}-\mathrm{H} s p^{3}\right), 1732(\mathrm{C}=\mathrm{O}), 1300-1600,1208(\mathrm{C}=\mathrm{C}$ aromatic), 1105 (C-O ether). Spectrum of ${ }^{1} \mathrm{H}-\mathrm{NMR}$ (500 MHz, acetone-d6) $\delta_{\mathrm{H}}(\mathrm{ppm}): 2.81(1 \mathrm{H}, d d, J=17.0$; $3.0 \mathrm{~Hz}), 3.16(1 \mathrm{H}, d d, J=17.5 ; 12.5 \mathrm{~Hz}) ; 5.54(1 \mathrm{H}, d d$, $J=13.0 ; 3.0 \mathrm{~Hz}) ; 6.01(2 \mathrm{H}, d d, J=13.5 ; 2.0 \mathrm{~Hz}), 7.37-$ 7,46 $(3 \mathrm{H}, m) ; 7.55(2 \mathrm{H}, d, J=7.5 \mathrm{~Hz}), 9.67(1 \mathrm{H}, s)$, $12.17\left(1 \mathrm{H}_{\text {chelated }}, s\right)$. Spectrum of ${ }^{13} \mathrm{C}-\mathrm{NMR}(125 \mathrm{MHz}$, acetone-d6) $\delta_{\mathrm{C}}(\mathrm{ppm}): 43.6 ; 79.9 ; 95.9 ; 97.1 ; 103.2$; 127.2 (2C); 129.4 (2C); 129.5; 140.1; 164.1; 165.2; 167.3 and 196.7. HRMS-ESI-TOF: $\mathrm{m} / \mathrm{z}[\mathrm{M}+\mathrm{H}]^{+}$calcd. for $\mathrm{C}_{15} \mathrm{H}_{12} \mathrm{O}_{4}$ 257.0814, found 257.0815.

4-hydroxybenzaldehyde (3), a pale yellow crystalline, MP: $120.1-120.4^{\circ}$. Spectrum of FTIR $(\mathrm{KBr}), v_{\max }\left(\mathrm{cm}^{-1}\right)$ : $3612(\mathrm{OH}), 1749(\mathrm{C}=\mathrm{O}), 1590,1505,1451 \quad(\mathrm{C}=\mathrm{C}$ aromatic), 1158 (C-O), para-disubstituted benzene $\left(835 \mathrm{~cm}^{-1}\right)$. Spectra ${ }^{1} \mathrm{H}-\mathrm{NMR}$ (acetone- $d_{6}, 500$ MHz): 9.85 (1H, $s, \mathrm{H}-6), 9.37(1 \mathrm{H}, b r s, 4-\mathrm{OH}), 7.81$ $(2 \mathrm{H}, \mathrm{d}, J=10 \mathrm{~Hz}, \mathrm{H}-2 / 4), 7.02$ (2H, d, $J=5 \mathrm{~Hz}, \mathrm{H}-3 / 5)$. Spectra ${ }^{13} \mathrm{C}-\mathrm{NMR}$ (acetone- $d, 125 \mathrm{MHz}$ ): 191.1 (C-6), 163.9 (C-4), 132.9 (C-2/4), 130.5 (C-1), 116.7 (C-3/5). HRMS-ESI-TOF: $\mathrm{m} / \mathrm{z}[\mathrm{M}+\mathrm{H}]^{+}$calcd. for $\mathrm{C}_{7} \mathrm{H}_{4} \mathrm{O}_{2} 121.0290$, found 121,0287 .

Three known compounds have been isolated and identified from $A$. occidentale stem barks that are pinostrobin, pinocembrin and 4-hydroxybenzaldehyde. Previously, the compound 1 and 2 were obtained jointly from Boesenbergia rotunda ${ }^{[36]}$, Kaempferia 
pandurata $^{[37]}$, and Piper ecuadoresense ${ }^{[38]}$. While some plant only produces pinostrobin namely Polygonum lapathifolium ${ }^{[39]}$, Cajanus cajan $^{[40]}$, and Renealmia alpinia ${ }^{[41]}$. The plant, which produces the only pinocembrin is Teloxys graveolens ${ }^{[15]}$. In addition, 4-hydroxybenzaldehyde was produced by Mimusops elengi ${ }^{[42]}$. According to the above information, the presence of pinostrobin, pinocembrin and 4-hydroxybenzaldehyde from the stem barks of $A$. occidentale is the first research report. The compound structures are showed in fig. 1.

Compound 1 was isolated as a yellow amorphous powder with MP: $102-103^{\circ}$. The spectrum of UV/Vis (methanol) $\lambda_{\max } 288 \mathrm{~nm}$ showed that the compound has chromophore of the conjugated unsaturated carbonyl. The presence of carbonyl group was supported by FTIR spectra, which have a strong stretching band of $\mathrm{C}=\mathrm{O}$ at $1649 \mathrm{~cm}^{-1}$. FTIR spectra also displayed the presence hydroxyl unit that revealed a broad absorbance band at $3430 \mathrm{~cm}^{-1}$ and the vibration band at $1158 \mathrm{~cm}^{-1}$ indicated the $\mathrm{C}-\mathrm{O}$ bending. Moreover, the presence of aromatic ring was indicated by peaks at 1510, 1445, 1401 $\mathrm{cm}^{-1}$. According to FTIR data, compound 1 comprises hydroxyl, carbonyl, and aromatic units. This prediction was verified by NMR $\left({ }^{1} \mathrm{H}\right.$ and $\left.{ }^{13} \mathrm{C}\right)$ data. The ${ }^{13} \mathrm{C}-\mathrm{NMR}$ spectrum analysis exhibited that the compound comprised fourteen signals for sixteen carbon atoms, two pairs of them are symmetrical carbons. The sixteen carbons include twelve aromatic carbons i.e. at $\delta_{\mathrm{C}}(\mathrm{ppm}) 102.7(\mathrm{C}-4 \mathrm{a}), 163.7(\mathrm{C}-5), 93.9$ (C-6), 167.5 (C-7), 94.7 (C-8), 162.4 (C-8a), 138.1 (C-1'), 125.8, 128.5, (C-2'/6', symmetry), 128.4, 128.5 (C$3, / 5$, symmetry), three aliphatic carbons at $\delta_{\mathrm{C}}(\mathrm{ppm})$ 78.7 (C-2) and 42.8 (C-3) and also a carbonyl carbon at $\delta_{\mathrm{C}} 195.4 \mathrm{ppm}$. The attendance two pair symmetrical carbons were confirmed by ${ }^{1} \mathrm{H}$ NMR data at $\delta_{\mathrm{H}}(\mathrm{ppm})$ $7.33(2 \mathrm{H}, m)$ and $7.39(2 \mathrm{H}, m)$. One shielded proton has a highly chemical shift at $\delta_{\mathrm{H}} 12.04 \mathrm{ppm}$. It is caused by chelating proton of hydroxyl unit (C-5) with the oxygen atom of the carbonyl group. This spectral data are characteristic for chelated 5-OH flavones and flavanones ${ }^{[38]}$.

Consistent with data of FTIR, NMR 1-D $\left({ }^{13} \mathrm{C},{ }^{1} \mathrm{H}\right)$, and comparison NMR 1-D data of isolated compound to the same data from the reference such as displayed in Table $1^{[35]}$ showed that compound 1 has high similarity parameters with pinostrobin (fig. 1). It can be concluded that compound 1 is pinostrobin. The conclusion was confirmed by NMR 2-D (HMBC) and mass spectroscopy (MS) data. The MS (HRMS-ESITOF) spectrum of compound 1 showed molecular ion $[\mathrm{M}+\mathrm{H}]^{+}$at $\mathrm{m} / \mathrm{z} 271,0970$ corresponding to molecular formula $\mathrm{C}_{16} \mathrm{H}_{14} \mathrm{O}_{4}$. It was further indicated that compound 1 is pinostrobin.

Structure elucidation stages of compounds 2 and 3 are the same as structure elucidation of compound 1 , which refers to the spectroscopy data including spectroscopy UV, FTIR, NMR 1-D, NMR 2-D and mass spectroscopy. Consistent with all spectroscopy data, compound 2 is pinocembrin ${ }^{[35]}$ and compound 3 is 4-hydroxybenzaldehyde ${ }^{[42]}$.

Leaves and stem barks extracts of $A$. occidentale were active materials against $E$. coli, $S$. aureus, $S$. epidermidis, P. aeruginosa, P. mirabilis, M. luteus, P. vulgaris, S. oralis, E. faecalis, and C. albicans ${ }^{[19]}$. Besides that, the stem barks also have potency as an antioxidant ${ }^{[20,21]}$. To support the potency of the plant tissue extracts, three compounds, which were isolated from methanol extract, were evaluated for their biological activities against some bacteria and DPPH (radical scavenger).

Pinostrobin and pinocembrin are flavonoid derivatives. A number of biological activities of the compounds have been reported. As antibacterial, pinocembrin is an active compound towards Bothrops asper ${ }^{[41]}$, while pinostrobin has potency for antibacterial against $E$. coli, B. subtilis, S. dysenteriae ${ }^{[43]}$. To continue antibacterial

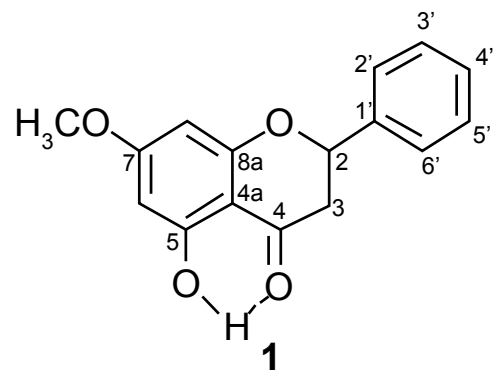<smiles>O=C1CC(c2ccccc2)Oc2cc(O)cc(O)c21</smiles><smiles>O=Cc1ccc(O)cc1</smiles>

Fig. 1: Structure of isolated compounds from stem barks of $A$. occidentale 1: Pinostrobin, 2: pinocembrin, 3: 4-hydroxybenzaldehyde 
properties study of pinostrobin, pinocembrin and 4-hydroxybenzaldehyde, we evaluated their activities against $S$. dysenteriae, $S$. typhi, MRSA and E. coli such as presented in Table 2. Generally, all isolated compounds are active towards all the tested bacteria. It supports the activity of methanol extracts of A. occidentale stem barks against some bacteria, which reported by Rout ${ }^{[19]}$. However, those isolated compounds are less active than chloramphenicol (positive control). Of the three isolated compounds, pinocembrin is the most active compound toward all selected bacteria. To further study on antiinfective potency, the $\mathrm{MIC}_{50}$ data of $\mathrm{MeOH}$ extracts and isolated compounds of $A$. occidentale stem barks were displayed in Table 3. According to Cos et al. ${ }^{[44]}$, for all antiinfective bioassays, the $\mathrm{IC}_{50}$ of pure compounds should be below $25 \mu \mathrm{M}$ and for mixtures less than $100 \mu \mathrm{g} / \mathrm{ml}$ (Table 4). Based on the reference, the methanol extracts included in a prospective antiinfective materials, while pinocembrin not included in the grade. Considering to the MIC value, can be concluded that strong antibacterial activity of the methanol extracts is not caused by these isolated compounds. An extensive investigation of all secondary metabolites present in

\section{TABLE 1: COMPARISON OF NMR DATA BETWEEN ISOLATED COMPOUND AND PINOSTROBIN ${ }^{[35]}$}

\begin{tabular}{|c|c|c|c|c|c|}
\hline \multirow[b]{2}{*}{ No. } & \multicolumn{3}{|c|}{ Compound 1} & \multicolumn{2}{|l|}{ Pinostrobin } \\
\hline & $\begin{array}{c}\delta \mathrm{H} \\
\text { (multiplicity, } J \text { in } \mathrm{Hz} \text { ) }\end{array}$ & $\delta C(p p m)$ & HMBC correlations & $\begin{array}{c}\delta \mathrm{H} \\
\text { (multiplicity, } J \text { in } \mathrm{Hz} \text { ) }\end{array}$ & $\delta C(\mathrm{ppm})$ \\
\hline 2 & $5.26(1 \mathrm{H}, d, J=3.0)$ & 78.7 & $C-2^{\prime} / 6^{\prime}, C-1^{\prime}, C-4$ & $5.39(\mathrm{dd}, J=12.84,2.76 \mathrm{~Hz}, 1 \mathrm{H})$ & 79.0 \\
\hline 3 & $\begin{array}{c}1.68(1 \mathrm{H}, d d, J=14.50,3.02 \\
\mathrm{Hz}) \\
2.95(1 \mathrm{H}, d d, J=16.53,2.40 \mathrm{~Hz})\end{array}$ & 42.8 & C-4 & $\begin{array}{l}2.79(\mathrm{dd}, J=14.68,2.76 \mathrm{~Hz}, 1 \mathrm{H}) \\
3.06(\mathrm{dd}, J=15.18,12.81 \mathrm{~Hz}, 1 \mathrm{H})\end{array}$ & 43.2 \\
\hline 4 & - & 195.4 & & & 195.7 \\
\hline $4 a$ & - & 102.7 & & & 103.0 \\
\hline 5 & - & 163.7 & & & 162.7 \\
\hline 6 & $5.97(1 \mathrm{H}, d, J=4.0)$ & 93.9 & $C-8, C-4 a$ & $6.05(\mathrm{~d}, J=2.72 \mathrm{~Hz}, 1 \mathrm{H})$ & 94.1 \\
\hline 7 & - & 167.5 & & & 167.8 \\
\hline 8 & $6.02(1 \mathrm{H}, d, J=4.0)$ & 94.7 & $C-6, C-4 a$ & $6.05(\mathrm{~d}, J=2.72 \mathrm{~Hz}, 1 \mathrm{H})$ & 95.0 \\
\hline $8 a$ & - & 162.4 & & & 164.0 \\
\hline $1^{\prime}$ & - & 138.1 & & & 138.3 \\
\hline $2^{\prime} / 6^{\prime}$ & $7.33(2 \mathrm{H}, \mathrm{m})$ & $125.8(2 C)$ & $C-2^{\prime} / 6^{\prime}$ & $7.41(\mathrm{~m}, 2 \mathrm{H})$ & 126.0 \\
\hline 3'/5' & $7.39(2 \mathrm{H}, \mathrm{m})$ & $128.5(2 C)$ & $\begin{array}{l}C-2, C-2^{\prime} / 6^{\prime}, \\
C-3^{\prime} / 5^{\prime}, \text { C-4' }\end{array}$ & $7.41(\mathrm{~d}, J=7.63,2 \mathrm{H})$ & 126.0 \\
\hline $4^{\prime}$ & $7.36(1 \mathrm{H}, m)$ & 128.4 & $\mathrm{C}-3^{\prime} / 5^{\prime}, \mathrm{C}-4^{\prime}, \mathrm{C}-1^{\prime}$ & $7.41(\mathrm{~d}, 7.27 \mathrm{~Hz}, 1 \mathrm{H})$ & 128.8 \\
\hline $\mathrm{O}-\mathrm{CH}_{3}$ & $3.68(3 \mathrm{H}, \mathrm{s})$ & 55.2 & C-7 & $3.79(\mathrm{~s}, 3 \mathrm{H})$ & 55.6 \\
\hline$-\mathrm{OH}_{\text {chelated }}$ & $12.04(1 \mathrm{H}, \mathrm{s})$ & - & $C-6, C-4 a, C-5$ & $12.00(1 \mathrm{H}, \mathrm{s}, 5-\mathrm{OH})$ & \\
\hline
\end{tabular}

$\delta \mathrm{H}$ is chemical shift of proton, $\delta \mathrm{C}$ is chemical shift of carbon, $\mathrm{J}$ is coupling constant, ppm is part per million

TABLE 2: INHIBITION ZONE OF METHANOL EXTRACTS AND ISOLATED COMPOUNDS

\begin{tabular}{lcccc}
\hline \multirow{2}{*}{ Compounds } & \multicolumn{4}{c}{ Diameter of inhibition zone (mm) } \\
\cline { 2 - 5 } & S. dysenteriae & S. typhi & MRSA & E. coli \\
\hline MeOH extracts & $8.77 \pm 0.87$ & $6.43 \pm 0.67$ & $6.45 \pm 0.49$ & $7.32 \pm 0.57$ \\
Pinostrobin & $10.13 \pm 0.51$ & $9.50 \pm 0.48$ & $7.61 \pm 0.35$ & $8.12 \pm 0.46$ \\
Pinocembrin & $12.56 \pm 0.56$ & $11.50 \pm 0.76$ & $11.22 \pm 0.54$ & $12.34 \pm 0.68$ \\
4-hydroxybenzaldehyde & $9.32 \pm 0.44$ & $7.21 \pm 0.54$ & NA & $9.12 \pm 0.52$ \\
Chloramphenicol & $21.50 \pm 0.78$ & $19.58 \pm 0.66$ & $18.71 \pm 0.94$ & $19.69 \pm 0.88$ \\
\hline
\end{tabular}

$\mathrm{NA}=$ not active

TABLE 3: MIC $_{50}$ VALUES OF METHANOL EXTRACT AND ISOLATED COMPOUNDS

\begin{tabular}{lcccc}
\hline \multirow{2}{*}{ Compounds } & \multicolumn{3}{c}{ MIC $_{50}(\mathrm{ppm})$} \\
\cline { 2 - 5 } & S. dysenteriae & S. typhi & MRSA & E. coli \\
\hline MeOH extract & 62.5 & 62.5 & 62.5 & 62.5 \\
Pinostrobin & $250(925 \mu \mathrm{M})$ & $250(925 \mu \mathrm{M})$ & $500(1953 \mu \mathrm{M})$ & $250(925 \mu \mathrm{M})$ \\
Pinocembrin & $125(488 \mu \mathrm{M})$ & $125(488 \mu \mathrm{M})$ & $250(976 \mu \mathrm{M})$ & $125(488 \mu \mathrm{M})$ \\
4-hydroxybenzaldehyde & $250(2049 \mu \mathrm{M})$ & $500(4098 \mu \mathrm{M})$ & $\mathrm{NA}$ & $500(4098 \mu \mathrm{M})$ \\
\hline
\end{tabular}


TABLE 4: IC ${ }_{50}$ VALUES OF ISOLATED COMPOUNDS

\begin{tabular}{lc}
\hline Compounds & $\mathrm{IC}_{50}(\mu \mathrm{M})$ \\
\hline Pinostrobin & $149.72 \pm 0.18$ \\
Pinocembrin & $138.80 \pm 0.25$ \\
4-hydroxybenzaldehyde & $134.93 \pm 0.13$ \\
Vitamin C (standard) & $63.32 \pm 0.22$ \\
\hline
\end{tabular}

the $\mathrm{MeOH}$ extracts should be carried out to determine all possible active compounds.

In evaluating radical scavenger potency, qualitative experiments showed that all isolated compounds bleached the purple DPPH colour to pale yellow when the TLC plate on which they were sprayed by $0.2 \%$ of DPPH in methanol. It is indicated that those samples has potency as radical scavengers. In the quantitative DPPH radical scavenger assay, all isolated compounds were able to neutralize the DPPH free radicals but less active than positive control (vitamin C). DPPH radical scavenging ability was increased in a concentration dependent manner compared to ascorbic acid that used as the positive control of antioxidant. There is a positive correlation between antioxidant activity and isolated compound concentrations $(p<0.05)$. Radical scavenger potency of isolated compounds showed that 4-hydroxybenzaldehyde is more active than pinostrobin and pinocembrin. Meanwhile, pinocembrin was slightly more active than pinostrobin ${ }^{[37]}$.

\section{Acknowledgements:}

The authors are grateful to the Ministry of Research, Technology and Higher Education of the Republic of Indonesia for providing research grants under skim "Hibah Kompetensi 2015".

\section{Conflict of interest:}

No conflict of interest.

\section{Financial support and sponsorship:}

Nil.

\section{REFERENCES}

1. Sahidin, Hakim EH, Juliawaty LD, Syah YM, bin Din L, Ghisalberti EL, et al. Cytotoxic properties of oligostilbenoids from the tree barks of Hopea dryobalanoides. Z Naturforsch C 2005;60:723-7.

2. Juliawaty LD, Sahidin, Hakim EH, Achmad SA, Syah YM, Latip J, et al. A 2-arylbenzofuran derivative from Hopea mengarawan. Nat Prod Commun 2005;4:947-50.

3. Muhammad N, Din LB, Sahidin I, Hashim SF, Ibrahim N, Zakaria Z, et al. Acuminatol and other antioxidative resveratrol oligomers from the stem bark of Shorea acuminata. Molecules 2012;17:9043-55.

4. Sahidin, Ardiansyah, Taher M, Manggau MA. Terpenoids from the stem bark of Jatropha plants and their biological activities. Makara Sains 2011;15:106-10.

5. Sahidin, Yamin, Ginting S, Manggau MA, Lukman. Cytotoxic potency of diterpenes from Jatropha plants. Int J Pharm Pharm Sci 2013;5:3-6.

6. Sabandar CW, Ahmat N, Jaafar FM, Sahidin I. Medicinal property, phytochemistry and pharmacology of several Jatropha species (Euphorbiaceae): A review. Phytochemistry 2013;85:7-29.

7. Rosandy AR, Din LB, Yaacob WA, Yusoff NI, Sahidin I, Latip $\mathrm{J}$, et al. Isolation and characterization of compounds from the stem bark of Uvaria rufa (Annonaceae). Malaysian J Anal Sci 2013;17:50-8.

8. Al Muqarrabun LMR, Ahmat N, Ruzaina SAS, Ismail NH, Sahidin I. Medicinal uses, phytochemistry and pharmacology of Pongamia pinnata (L.) Pierre: A review. J Ethnopharmacol 2013; 150:395-420.

9. Ruslin, Asmawi MZ, Rianse U, Sahidin I, Dhianawaty D, Soemardji AA, et al. Anti-hypertensive activity of AlangAlang (Imperata cylindrica L.) Beauv. root methanolic extract on male Wistar rat. Int J Res Pharm Sci 2013;4:537-42.

10. Sahidin, Nohong, Sani A, Manggau MA, Sukohar A, Widodo $\mathrm{H}$, et al. Radical scavenging activity of triterpene steroids from stem of Polygonum pulchrum B1. Int J Pharm Pharm Sci 2014;6:350-4.

11. Sahidin I, Suwandi A, Nohong Manggau MA. Profile of anticancer and radical scavenging activities of steroids from stems of Polygonum pulchrum. IJPSR 2015;6:2178-84.

12. Jalil J, Sabandar CW, Ahmat N, Jamal JA, Jantan I, Aladdin NA, et al. Inhibitory effect of triterpenoids from Dillenia serrata (Dilleniaceae) on prostaglandin E2 production and quantitative HPLC analysis of its koetjapic acid and betulinic acid contents. Molecules 2015;20:3206-20.

13. Orwa $\mathrm{C}$, Mutua $\mathrm{A}$, Kindt $\mathrm{R}$, Jamnadass $\mathrm{R}$, Anthony $\mathrm{S}$. Agroforestree Database. Yenya: World Agroforestry Centre; 2009.

14. Ogata Y. Medicinal Herb Index in Indonesia. 2nd ed. Indonesia: PT Eisai; 2009.

15. Del Rayo CM, Sanchez B, Quiroz H, Contreras JL, Mata R. Pinocembrine: A bioactive flavanone from Teloxys graveolens. J Ethnopharmacol 1991;31:383-9.

16. Akinpelu DA. Antimicrobial activity of Anacardium occidentale bark. Fitoterapia 2001;72:286-7.

17. Ajileye OO, Obuotor EM, Akinkunmi EO, Aderogba MA. Isolation and characterization of antioxidant and antimicrobial compounds from Anacardium occidentale L. (Anacardiaceae) leaf extract. J King Saud Univ Sci 2015;27:244-52.

18. Encarnação S, Mello-sampayo CDe, Graça NAG, Catarino L, Moreira da Silva IB, Lima BS, et al. Total phenolic content, antioxidant activity and pre-clinical safety evaluation of an Anacardium occidentale stem bark Portuguese hypoglycemic traditional herbal preparation. Ind Crops Prod 2016;82:171-8.

19. Rout SP, Kar DM, Jagadeeshreddy E, Manoj S, Sengottuvel T. In vitro antioxidant property of fractions of Annona reticulata (L.) leaves. Int J Pharm Pharm Sci 2015;7:4-8.

20. Konan NA, Bacchi EM. Antiulcerogenic effect and acute toxicity of a hydroethanolic extract from the cashew 
(Anacardium occidentale L.) leaves. J Ethnopharmacol 2007;112:237-42.

21. Chabi SK, Sina H, Adoukonou-Sagbadja H, Ahoton LE, Roko GO, Saidou A, et al. Antimicrobial activity of Anacardium occidentale L. leaves and barks extracts on pathogenic bacteria. Afr J Microbiol Res 8:2458-67.

22. Mota ML, Thomas G, Barbosa Filho JM. Anti-inflammatory actions of tannins isolated from the bark of Anacardium occidentale L. J Ethnopharmacol 1985;13:289-300.

23. Olajide OA, Aderogba MA, Fiebich BL. Mechanisms of antiinflammatory property of Anacardium occidentale stem bark: inhibition of NF- $\mathrm{KB}$ and MAPK signalling in the microglia. J Ethnopharmacol 2013;9;145(1):42-9.

24. Himejima M, Kubo I. Antibacterial Agents from the Cashew Anacardium occidentale (Anacardiaceae) nut shell oil. J Agric Food Chem 1991;39:418-21.

25. Pawar SP, Sathwane PN, Metkar BR, Pal SC, Kasture VS, Kasture SB. Anti-inflammatory and analgesic activity of Anacardium occidentale leaf extracts. Anc Sci Life 2000;19:169-73.

26. Kannan VR, Sumathi CS, Balasubramanian V, Ramesh N. Elementary chemical profiling and antifungal properties of cashew (Anacardium occidentale L.). Bot Res Int 2009;2:253-7.

27. Shobha SV, Krishnaswamy PR, Ravindranath B. Phenolic lipid composition during development of Cashew. Phytochemistry 1992;31:2295-7.

28. Yuliana M, Nguyen-Thi BT, Faika S, Huynh LH, Soetaredjo $\mathrm{FE}, \mathrm{Ju}$ YH. Separation and purification of cardol, cardanol and anacardic acid from cashew (Anacardium occidentale L.) nutshell liquid using a simple two-step column chromatography. J Taiwan Inst Chem Eng 2014;45:2187-93.

29. Trox J, Vadivel V, Vetter W, Stuetz W, Kammerer DR, Carle $\mathrm{R}$, et al. Catechin and epicatechin in testa and their association with bioactive compounds in kernels of cashew nut (Anacardium occidentale L). Food Chem 2011;128P:1094-9.

30. Schweiggert RM, Vargas E, Conrad J, Hempel J, Gras $\mathrm{CC}$, Ziegler JU, et al. Carotenoids, carotenoid esters, and anthocyanins of yellow-, orange-, and red-peeled cashew apples (Anacardium occidentale L). Food Chem 2016;200:274-82.

31. Konan NA, Lincopan N, Díaz IE, de Fátima Jacysyn J, Tiba MM, Amarante Mendes JG. Cytotoxicity of cashew flavonoids towards malignant cell lines. Exp Toxicol Pathol 2012;64:435-40.
32. Brito ES, Damasceno LF, Fernandes FAN, Magalhães MMA. Non-enzymatic browning in clarified cashew apple juice during thermal treatment: Kinetics and process control. Food Chem 2008;106:172-9.

33. Saha A, Rahman MS. Antimicrobial activity of crude extract from Calycopteris floribunsa. Bangladesh J Microbiol 2010;25:137-9.

34. Nouvlessounon DD, Adoukonou-Sagbadja H, Diarrassouba N, Sina H, Noumavo PA, Baba-moussa F, et al. Antimicrobial, antioxidant, cytotoxic activities and phytochemical assessment of Cola acuminata used in Benin. Int J Pharm Pharm Sci 2015;7:102-9.

35. Ching AYL, Wah TS, Sukari MA, Lian GEC, Rahmani M, Khalid K. Characterization of flavonoid derivatives from Boesenbergia Rotunda L. MJAS 2007;11:154-9.

36. Gyamfi MA, Aniya Y. Antioxidant properties of Thonningianin A, isolated from the African medicinal herb, Thonningia sanguinea. Biochem Pharmacol 2002;1:1725-37.

37. Tanjung M, Tjahjandarie TS, Sentosa MH. Antioxidant and cytotoxic agent from the rhizomes of Kaempferia pandurata. Asian Pac J Trop Dis 2013;3(5):401-4.

38. Ramirez J, Cartuche L, Morocho V, Aguilar S, Malagon O. Antifungal activity of raw extract and flavanons isolated from Piper ecuadorense from Ecuador. Brazilian J Pharmacog 2013;23:370-3.

39. Smolarz HD, Mendyk E, Bogucka-Kocka A, Kocki J. Pinostrobin - An anti-leukemic flavonoid from Polygonum lapathifolium L. ssp. nodosum (Pers.) Dans. Z Naturforsch C 2006;61:64-8.

40. Patel NK, Bhutani KK. Pinostrobin and Cajanus lactone isolated from Cajanus cajan (L.) leaves inhibits TNF- $\alpha$ and IL-1 $\beta$ production: in vitro and in vivo experimentation. Phytomedicine 2014;15:946-53.

41. Gómez-Betancur I, Benjumea D, Patiño A, Jiménez N, Osorio E. Inhibition of the toxic effects of Bothrops asper venom by pinostrobin, a flavanone isolated from Renealmia alpinia (Rottb.) J Ethnopharmacol 2014;155:1609-15.

42. Rao VG, Sharlene C, Mukhopadhyay T. Secondary metabolites from the flowers of Mimusops elengi Linn. Der Pharmacia Lettre 2012;4:1817-20.

43. http://snkpk.fkip.uns.ac.id/wp-content/uploads/2015/03/ AKTIVITAS-ANTIBAKTERI-PINOSTROBIN-5-hidroksi7-metoksi-flavanon-DARI-Kaempferia-pandurata1.pdf.

44. Cos P, Vlietinck AJ, Berghe DV, Maes L. Anti-infective potential of natural products: How to develop a stronger in vitro 'proof-of-concept'. J Ethnopharmacol 2006;106:290-302. 